\title{
Assessment of Macro-Nutrient Status of Pear Orchards in Jammu and Kashmir, India
}

\author{
Sartaj A. Wani ${ }^{{ }^{*}}$, G.R. Najar ${ }^{1}$, Farida Akhter ${ }^{1}$, Bilal A. Padder ${ }^{2}$ and Masarat Maqbool ${ }^{1}$ \\ ${ }^{1}$ Division of Soil Science, Faculty of Agriculture, SKUAST-K, Wadura, Sopore, \\ J \& K-193201, India \\ ${ }^{2}$ Division of Fruit Science, SKUAST-K, Shalimar - 190 025, Srinagar, J \& K, India \\ *Corresponding author
}

\begin{tabular}{|c|c|}
\hline & A B S T R A C T \\
\hline & A reconnaissance survey was conducted to determine the macronutrient status of pear \\
\hline Keywords & $\begin{array}{l}\text { (Pyrus communis L.) growing orchards of district Pulwama in Kashmir during 2014-15. A } \\
\text { total of thirty six soil samples collected from each surface and sub-surface depths of }\end{array}$ \\
\hline $\begin{array}{l}\text { Correlation, } \\
\text { Macronutrients, } \\
\text { Pear orchards, } \\
\text { Soil properties. }\end{array}$ & $\begin{array}{l}\text { twelve representative profiles were analyzed for physico-chemical properties and } \\
\text { macronutrients. Results of the soil chemical analysis revealed that none of the surveyed } \\
\text { pear orchards was deficit in available macronutrients and were medium in available } \mathrm{N} \\
\left(292.88-414.67 \mathrm{~kg} \mathrm{ha}^{-1}\right) \text { and } \mathrm{P}\left(10.09-17.51 \mathrm{~kg} \mathrm{ha}^{-1}\right) \text {, medium to high in } \mathrm{K}(246.73-280.40\end{array}$ \\
\hline Article Info & $\begin{array}{l}\left.\mathrm{kg} \mathrm{ha}^{-1}\right) \text { and } \mathrm{Ca}(2010-2475 \mathrm{ppm}) \text {, low to medium in } \mathrm{Mg}(264.30-294.80 \mathrm{ppm}) \text { and } \mathrm{S} \\
(9.24-12.15 \mathrm{ppm}) \text { status respectively. In the present study the correlation studies showed }\end{array}$ \\
\hline $\begin{array}{l}\text { Accepted: } \\
\text { 26 May } 2017 \\
\text { Available Online: } \\
10 \text { June } 2017\end{array}$ & $\begin{array}{l}\text { that soil pH had significant influence on } \mathrm{N}, \mathrm{P}, \mathrm{Ca} \text { and } \mathrm{S} \text { availability. Organic carbon } \\
\text { showed significantly positive correlation in surface }\left(\mathrm{N}=0.603^{*}\right), \mathrm{P}\left(\mathrm{P}=0.379^{*}\right) \text { and } \\
\left(\mathrm{K}=0.414^{*}\right) \text { and sub-surface }\left(\mathrm{N}=0.747^{*}\right),\left(\mathrm{P}=0.429^{*}\right) \text { and }\left(\mathrm{K}=0.634^{*}\right) \text { soils respectively. } \\
\text { Addition of sufficient organic matter and proper nutrient management practices may serve } \\
\text { better for improving soil properties thereby enhancing the nutrient availability. }\end{array}$ \\
\hline
\end{tabular}

\section{Introduction}

The pear native of Central Asia, stands $2^{\text {nd }}$ in ranking after apples as the most important delectable tree fruits, is grown in all the continents of the world under warm temperate to temperate climatic conditions. Due to very high chilling requirements, the superior cultivars of pear (Pyrus communis) are confined to high hills of Jammu and Kashmir, Himachal Pradesh and Uttaranchal in India. The state of Jammu and Kashmir offers favourable agro-ecological potential for pear cultivation. Currently the area under pear fruit is 13883 ha with annual production of 54847 MT in our state (Anonymous, 2015). The low pear production is primarily owing to the poor soil fertility status besides improper management practices. The crop production and soil managements greatly differ with kind of soil and their physico-chemical behavior (Sharma et al., 2006). The production of quality fruit is also influenced by the fruit mineral composition, harvesting at maturity stage and leaf fruit ratio. The nutrient supplying power of a soil depends on dissociation of the nutrients from the exchange site, which is in turn depend on the degree of saturation of the nutrients on the exchange site, type of clay and complementary ion-effect (Foth and Ellis, 1997). Continued removal of nutrients, with 
little or no replacement has aggravated the potential for future nutrient related plant stress and yield loss. It is therefore, inevitable to consider the analysis assessing the nutritional availability of fruit growing crops with deep and ramified root system (Najar et al., 2005). Besides, knowledge of nutrient distribution down the profile is important to evaluate the contributions of different subsurface horizons. The excessive and repeated use of specific nutrient fertilizer has lead to nutritional imbalances through the decline of other necessary nutrients. Nutritional imbalances in the soil cause nutritional disorders and consequently affect both quality and quantity of fruits. A study has been therefore, conducted in pear growing orchards to determine the status of available macronutrients as well relationship with soil physico-chemical properties so as to use such knowledge as a tool in optimizing fertilizers use for better yield and quality.

\section{Materials and Methods}

Soil profiles were exposed in three established physiographic zones viz., high, mid and low altitudes respectively from twelve representative pear (Pyrus comunis L.) orchards of uniform age group (15-30 years) in Pulwama district of Jammu and Kashmir. Stratified random soil sampling was preferred due to large number of pear orchards present in this region. The soil samples collected at collected at surface and sub-surface $(0-30 \mathrm{~cm}$ and $30-90 \mathrm{~cm}$ ) depths respectively were air dried, crushed with wooden pestle and mortar and passed through $0.2 \mathrm{~mm}$ sieve. The processed composite soil samples were analyzed for physico-chemical properties and available macro-nutrients using standard procedure by Jackson (1973) and piper (1966). The available $\mathrm{N}, \mathrm{P}, \mathrm{K}, \mathrm{Ca}, \mathrm{Mg}$ and $\mathrm{S}$ were determined by methods outlined by their standard procedures. The concentration of calcium and magnesium in the extract was determined by atomic absorption spectrophotometer (AAS). The available status of $\mathrm{N}, \mathrm{P}, \mathrm{K}, \mathrm{Ca}, \mathrm{Mg}$ and $\mathrm{S}$ were categorized in sufficient and deficient categories by considering their critical limits as given by Subbiah and Asija (1956), $280 \mathrm{Kg}$ $\mathrm{ha}^{-1}$ for $\mathrm{N}$; Olsen et al., (1954), $8.96 \mathrm{Kg} \mathrm{ha}^{-1}$ for P, Hanway and Heidal (1952), $98.56 \mathrm{Kg}$ ha $^{-1}$ for K; and Kanwar and Mohan (1964), 10 ppm for $\mathrm{S}$ respectively. Simple correlation coefficients were computed relating macronutrients with different physicochemical properties (Panse and Sukhatame, 1967).

\section{Results and Discussion}

All the surface soil samples at $95 \% \mathrm{CI}$, were medium in available $\mathrm{N}$ (292.88-414.67), $\mathrm{P}$ (10.09-17.51) and $\mathrm{Mg}$ (264.30-294.80), medium to high in available K (246.73$280.40 \mathrm{~kg} \mathrm{ha}^{-1}$ ) and $\mathrm{Ca}$ (2010-2475) and low to medium in available $\mathrm{S}(9.24-12.15 \mathrm{ppm})$ with the average values of $357.33,14.81$, $277.60,263.05 \mathrm{~kg} \mathrm{ha}^{-1}, 2267.50$ and 10.92 ppm respectively. In case of sub-surface soils at $95 \% \mathrm{CI}$, content varied from 191.98-245.60 N, 10.02-11.39 P, 206.49-219.06 K 2141.602417.89 $\mathrm{Ca}, 259.65-274.78 \mathrm{Mg}$ and 8.97$9.91 \mathrm{~S} \mathrm{ppm}$ with average values of 218.78 , $10.71,213.51 \mathrm{~kg} \mathrm{ha}^{-1}, 2279.7,267.22$ and 9.44 ppm respectively (Table 1). Similar results for macronutrient status were reported by Dar et al., (2012) while studying the pear orchards in Kashmir. In the present study, macronutrients like $\mathrm{N}, \mathrm{P}, \mathrm{Mg}$ and $\mathrm{S}$ showed significant difference (using t-test at $\mathrm{p}<0.05$ ) between surface and sub-surface soil depths.

Macronutrients like $\mathrm{N}, \mathrm{P}$ and $\mathrm{S}$ were significant and negatively related with $\mathrm{pH}$ in both surface and sub-surface soils with correlation coefficients as shown in table 2 . The availability of phosphorus decreases with increase in soil $\mathrm{pH}$ because of its conversion into insoluble tricalcium phosphates. Similar 
relationship between $\mathrm{pH}$ and available phosphorus was reported by Najar (2005) and Dar et al., (2012). Significant and positive relationship between soil $\mathrm{pH}$ and calcium $(0.579 *$ and $0.524 *)$ indicates the basic nature of calcium. Such findings were reported by Wani (2001) and Dar et al., (2012). Nonsignificant but negative correlation of EC with macronutrients was reported by Khokhar et al., (2012). A significant and positive correlation of organic carbon with $\mathrm{N}, \mathrm{P}$ and $\mathrm{K}$ was observed in both surface $\left(0.603^{*}, 0.379^{*}\right.$ and $\left.0.414^{*}\right)$ and sub-surface $\left(0.747^{*}, 0.429^{*}\right.$ and $0.634^{*}$ ) soils indicated that organic matter contributed to the major fraction of these nutrients. The increase in available nitrogen could be attributed to the association of nitrogen with organic matter and adsorption of $\mathrm{NH}_{4}-\mathrm{N}$ by humus complexes in soils.

Table.1 Depth-wise distribution of available macronutrients pear orchards

\begin{tabular}{|c|c|c|c|c|c|c|c|}
\hline \multirow{2}{*}{ Location } & \multirow{2}{*}{$\begin{array}{l}\text { Depth } \\
\text { (cm) }\end{array}$} & $\mathbf{N}$ & $\mathbf{P}$ & $\mathbf{K}$ & $\mathbf{C a}$ & Mg & $\mathbf{S}$ \\
\hline & & \multicolumn{3}{|l|}{$\left(\mathrm{kg} \mathrm{ha}^{-1}\right)$} & \multicolumn{3}{|l|}{ (ppm) } \\
\hline \multirow[b]{2}{*}{ Tujan } & $0-30$ & 408.80 & 17.00 & 271.44 & 2114 & 285.90 & 9.24 \\
\hline & $30-90$ & 273.38 & 12.13 & 228.01 & 2063 & 257.6 & 9.76 \\
\hline \multirow[b]{2}{*}{ Rohomu } & $0-30$ & 414.67 & 13.14 & 265.43 & 2410 & 275.70 & 11.78 \\
\hline & $30-90$ & 250.74 & 9.92 & 216.91 & 2214 & 282.72 & 10.13 \\
\hline \multirow[b]{2}{*}{ Newa } & $0-30$ & 394.91 & 17.20 & 280.40 & 2010 & 278.40 & 10.65 \\
\hline & $30-90$ & 264.26 & 11.68 & 216.02 & 2369 & 264.16 & 8.74 \\
\hline \multirow[t]{2}{*}{ Khrew } & $0-30$ & 381.80 & 15.85 & 278.98 & 2252 & 264.30 & 12.15 \\
\hline & \begin{tabular}{|l|}
$30-90$ \\
\end{tabular} & 284.12 & 12.05 & 217.32 & 2449 & 272.43 & 9.00 \\
\hline \multirow{2}{*}{ Newa } & $0-30$ & 373.14 & 15.74 & 267.37 & 2148 & 289.56 & 11.00 \\
\hline & $30-90$ & 231.72 & 11.38 & 214.58 & 2029 & 282.00 & 10.03 \\
\hline \multirow[t]{2}{*}{ Bundzoo } & $0-30$ & 360.46 & 17.51 & 250.64 & 2475 & 283.65 & 11.90 \\
\hline & $30-90$ & 218.87 & 11.98 & 202.18 & 2234 & 287.10 & 9.98 \\
\hline \multirow{2}{*}{ Chakora } & $0-30$ & 349.08 & 14.13 & 257.17 & 2334 & 276.94 & 10.38 \\
\hline & \begin{tabular}{|l|}
$30-90$ \\
\end{tabular} & 195.64 & 9.43 & 211.81 & 2622 & 254.12 & 8.84 \\
\hline \multirow[t]{2}{*}{ Urcherso } & $0-30$ & 329.84 & 11.77 & 260.12 & 2290 & 294.80 & 10.12 \\
\hline & \begin{tabular}{|l|}
$30-90$ \\
\end{tabular} & 208.18 & 9.85 & 226.44 & 2253 & 270.13 & 8.30 \\
\hline \multirow{2}{*}{$\begin{array}{l}\text { Katibug } \\
\text { h }\end{array}$} & $0-30$ & 345.36 & 15.26 & 255.48 & 2180 & 268.74 & 11.74 \\
\hline & \begin{tabular}{|l|}
$30-90$ \\
\end{tabular} & 191.28 & 10.86 & 20.4 .69 & 1878 & 259.23 & 10.40 \\
\hline \multirow{2}{*}{ Pampore } & $0-30$ & 292.88 & 11.78 & 260.42 & 2325 & 272.54 & 11.02 \\
\hline & $30-90$ & 181.21 & 10.0 & 212.56 & 2282 & 267.8 & 9.70 \\
\hline \multirow[t]{2}{*}{ Pahu } & $0-30$ & 324.48 & 12.72 & 246.73 & 2242 & 276.35 & 10.00 \\
\hline & $30-90$ & 167.08 & 9.84 & 192.25 & 2427 & 251.7 & 8.37 \\
\hline \multirow[t]{2}{*}{ Gundbag } & $0-30$ & 312.57 & 10.09 & 262.42 & 2430 & 264.38 & 10.38 \\
\hline & $30-90$ & 158.92 & 9.38 & 210.53 & 2537 & 257.63 & 10.05 \\
\hline \multirow{2}{*}{ Surface } & \begin{tabular}{|l} 
Average \\
\end{tabular} & 357.33 & 14.81 & 263.05 & 2267.5 & 277.60 & 10.92 \\
\hline & $95 \% \mathrm{CI}$ & $292.88-414.67$ & $10.09-17.51$ & $246.73-280.40$ & $2010-2475$ & $264.30-294.80$ & $9.24-12.15$ \\
\hline \multirow{2}{*}{$\begin{array}{l}\text { Sub- } \\
\text { surface }\end{array}$} & Average & 218.78 & 10.71 & 213.51 & 2279.70 & 267.22 & 9.44 \\
\hline & $95 \% \mathrm{CI}$ & 191.98-245.60 & $10.02-11.39$ & 206.49-219.06 & $2141.60-2417.89$ & $259.65-274.78$ & $8.97-9.91$ \\
\hline Surface & \multirow[b]{2}{*}{ p-value } & \multirow[b]{2}{*}{0.0001} & \multirow[b]{2}{*}{0.0001} & \multirow[b]{2}{*}{0.068} & \multirow[b]{2}{*}{0.343} & \multirow[b]{2}{*}{0.017} & \multirow[b]{2}{*}{0.001} \\
\hline $\begin{array}{l}\text { Sub- } \\
\text { surface }\end{array}$ & & & & & & & \\
\hline
\end{tabular}

$95 \% \mathrm{CI}=$ Confidence Interval at 95 per cent 
Table.2 Relationship between physico-chemical properties and Available macronutrients of tested pear orchard soil samples

\begin{tabular}{|l|l|l|l|l|l|l|l|l|l|l|}
\hline \multirow{2}{*}{ Nutrient } & \multicolumn{4}{|l}{ Surface soils (0-30) } & \multicolumn{4}{l|}{ Sub-surface soils (30-90) } \\
\cline { 2 - 11 } & $\mathbf{p H}$ & $\mathbf{E C}$ & $\mathbf{O C}$ & $\begin{array}{l}\mathbf{C a C O}_{\mathbf{3}} \\
(\boldsymbol{\%})\end{array}$ & $\mathbf{C l a y}$ & $\mathbf{p H}$ & $\mathbf{E C}$ & $\mathbf{O C}$ & $\begin{array}{l}\text { CaCO } \\
(\boldsymbol{\%})\end{array}$ & Clay \\
\hline $\mathrm{N}$ & $-0.577^{*}$ & -0.564 & $0.603^{*}$ & $-0.614^{*}$ & -0.053 & $-0.767^{*}$ & -0.384 & $0.747^{*}$ & $-0.480^{*}$ & 0.320 \\
\hline $\mathrm{P}$ & $-0.623^{*}$ & -0.490 & $0.379^{*}$ & -0.421 & -0.146 & $-0.643^{*}$ & -0.133 & $0.429^{*}$ & $-0.346^{*}$ & 0.152 \\
\hline $\mathrm{K}$ & -0.123 & -0.382 & $0.414^{*}$ & $-0.507^{*}$ & 0.125 & $-0.428^{*}$ & -0.158 & $0.634^{*}$ & $-0.424^{*}$ & 0.512 \\
\hline $\mathrm{Ca}$ & $0.579^{*}$ & 0.287 & -0.312 & $0.468^{*}$ & 0.233 & $0.524^{*}$ & 0.088 & -0.147 & $0.397^{*}$ & -0.476 \\
\hline $\mathrm{Mg}$ & -0.314 & 0.322 & 0.216 & $0.369^{*}$ & 0.058 & -0.333 & 0.007 & -0.298 & $0.451^{*}$ & -0.054 \\
\hline $\mathrm{S}$ & $-0.489^{*}$ & -0.457 & 0.115 & -0.058 & 0.007 & $-0.502^{*}$ & -0.156 & 0.399 & $-0.474^{*}$ & 0.014 \\
\hline
\end{tabular}

* Significant at 5 per cent level

Similar results were earlier reported by Najar et al., (2006), Dar (2012) and Singh \& Rathore (2014). The increase in availability of nitrogen, phosphorus and sulphur may be attributed to the release of these elements from organic complexes as well as from the weathering of minerals containing due to acidulating action of organic matter. These results are in conformity with the findings of Wani (2001), Farida (2005) and Singh \& Rathore (2014). Calcium carbonate showed significantly negative relationship with nitrogen and potassium in surface and subsurface soils and with phosphorus $\left(-0.346^{*}\right)$ and sulphur $\left(-0.474^{*}\right)$ in sub-surface soils only. Similar relationship was earlier reported by Najar (2005) and Dar et al., (2012). Significant but positive correlation of calcium carbonate with calcium and magnesium results from increase in $\mathrm{pH}$ due to calcium carbonate thereby increasing calcium and magnesium. Such findings were reported by Wani (2001) and Dar et al., (2012).

Considering the critical limit of macronutrients, the studied orchards are $100 \%$ medium in available $\mathrm{N}, \mathrm{P}, \mathrm{Ca}$ and $\mathrm{Mg}$, $8 \%$ high in available $\mathrm{K}$ and $17 \%$ low in available S. Although $\mathrm{S}$ was low in some orchards, all other pear orchard soils were adequate in available macronutrients. The results further indicated that the soil $\mathrm{pH}$ and OC play major role in controlling the availability of macronutrients. These factors could be manipulated in order to combat any present or future deficiencies of macronutrients in these soils.

\section{References}

Anonymous 2015. Area and production of horticultural crops in Jammu and Kashmir State. Department of Horticulture. J\&K Government.

Dar, M. A., Wani. J. A., Raina, S. K, Bhat M. Y., Dar. M. A. 2012. Effect of available nutrients on yield and quality of pear fruit Bartlett in Kashmir Valley, India. Journal of Environmental Biology. 33:1011-1014.

Farida, A. 2005. Studies on relationship between fruit yield and quality with soil and leaf nutrient content in apple orchards of Zangier block of district Baramulla Kashmir. Ph. D thesis submitted to SKUAST-Kashmir, Srinagar, pp 117.

Foth, H.D. and Ellis, B.G. 1997. Soil fertility, 2nd Ed. Lewis CRC Press LLC., USA. 290p. Kanwar, J.S. and Mohan, S. 1964. Distribution of forms of sulphur in Punjab soils. Symposium on Fertilization in Indian Soils. Bulletin National Institute of Science, India 20: 31-36.

Hanway, J.J. and Heidel, H. 1952. Soil 
analysis methods as used in Iowa State College soil testing laboratory. Iowa State College of Agriculture Bulletin 57: 1-31

Jackson, M.L. 1973. Soil Chemical Analysis. Prentice Hall of India Private Limited, New Delhi.

Khokhar, Y., Rattanpal, H. S., Dhillon, W. S., Singh, G. and Gill, P. S., 2012. Soil fertility and nutritional status of Kinnow orchards grown in aridisol of Punjab, India. African Journal of Agricultural Research 7: 4692-4697.

Lindsay, W.L. and Norwell, W.A. 1978. Development of DTPA soil test of ascertaining available $\mathrm{Fe}, \mathrm{Cu}, \mathrm{Mn}$ and Zn. Soil Sci. Soc. Amer.J. 42: 421-27.

Najar, G.R., Akhtar, F. and Rahman, F.H. 2005. Mineral nutrient status of Apple orchards of Kashmir. SKUAST Journal of Research 7(2): 271-275.

Olsen, S.R. and Sommers, L.E. 1982. Phosphorus. Methods of soil analysis, Part 2, pp 403-430.

Panse, V.G. and Sukhatame, P.V. 1967. Statistical Methods for Agricultural Workers. Indian Council of Agricultural Research, New Delhi
Piper, C.S. 1966. Soil and Plant Analysis. $5^{\text {th }}$ edition. Hans Publisher, Bombay, p 464.

Sharma, V. K., Dwivedi, K. S., Tripathi, D. and Ahmed, Z. 2006. Status of available major and micronutrients in the soils of different blocks of Leh district of cold arid region of Ladakh in relation to soil characteristics. Journal of the Indian Society of Soil Science 54: 248-250.

Singh, D. P. and Rathore, M.S. 2014. Available nutrient status and their relationship with soil properties of Aravalli mountain ranges and Malwa Plateau of Pratapgarh, Rajasthan, India. African Journal of Agricultural Research 8(41): 5096-5103.

Subbiah, B.V. and Aaija, G.L. 1956. A rapid procedure for the estimation of availability nitrogen in soils. Current Science 25: 259-260.

Wani, G.N. 2001. Studies on the distribution of secondary nutrient elements $(\mathrm{Ca}, \mathrm{Mg}$ and $\mathrm{S}$ ) in apple orchard soils of north Kashmir. Thesis submitted to SKUAST-Kashmir, pp. 75.

\section{How to cite this article:}

Sartaj A. Wani, G.R. Najar, Farida Akhter, Bilal A. Padder and Masarat Maqbool. 2017. Assessment of Macro-Nutrient Status of Pear Orchards in Jammu and Kashmir, India. Int.J.Curr.Microbiol.App.Sci. 6(6): 2720-2724. doi: https://doi.org/10.20546/ijcmas.2017.606.324 